\title{
LEITURA DO POEMA "VELHO VENTO", DE CRUZ E SOUSA
}

\section{ROBERTO REIS}

O poema "Velho vento", de Cruz e Sousa $\left.{ }^{1}\right]$, compõe-se de trinta quartetos, com o esquema rímico $A B B A$, sendo que a acentuação oscila, basicamente, entre as $1 .^{\circ}, 3 .^{\circ} \mathrm{e} 7 .^{\circ} \mathrm{e}$ as $2 .^{\circ}, 4 .^{\circ}$ e $7 .^{\circ}$ silabas (vale dizer: há um acento no princípio, meio e fim do verso). Poderíamos nos deter no exame do material morfo-sintático e do material fônico, ou aprofundar o estudo da matéria e da rima, a que fizemos ligeira menção, a exemplo de Domício Proença Filho $\left({ }^{2}\right)$, e, com certeza, reencontraríamos idênticos elementos formais para corroborar a estética simbolista, piasmada no poema. Optamos, entretanto, por uma abordagem do aspecto semântico do texto - que, no comentário a que o Prof. Domício submete o soneto "Cárcere das almas", se confunde com um mero levantamento do vocabulário e reconhecimento das metáforas $\left({ }^{3}\right)$-, tentando rastrear algumas das características estabelecidas por Hibbard $\left({ }^{4}\right)$ para este estilo de época, para extrapolá-las em seguida.

Nessa linha de trabalho, podemos tomar como ponto de partida as palavras de Tasso da Silveira, em nota de rodapé, sobre as metáforas que sustentam "Velho vento": "o vento é todas essas coisas, principalmente a energia capaz de levar o lamento do poeta para "além do escárnio do mundo" - ao final é sugerida a problemática fulcral do poema, qual seja a oposição entre duas realidades.

1 Cruz e Souso, Poesia (ontdiogia), 3.' ed. (Rio de Janeiro: Liv. Agir Ed., 1967).

2 Estilos de Época na literatura, 2.a ed. (Rio de Janeiro: Ed. Liceu, 1969). CapiApresentação de Tasso da Silveira.

2 Estilos de época na literatura, $2 .^{\circ}$ ed. (Rio de Janeiro: Ed. Liceu, 1969). Capitulo X, "O Simbolismo", pp. 233-41.

3 Op. cit., p. 237.

4 Cit. por Afránio Coutinho, Introdução d literatura no 8rasil, 4.a ed. (Rio de Janeiro: Liv. São José, 1969), p. 219. Habibard é mencionsdo por Domicio Proença Filho que, neste e em outros momentos, segue bem de perto as pegadas do trabalho do Prof. Afranio Coutinho sobre os estlios de época. 
Com efeito, à simples leitura, percebe-se que é desenhado, ao longo de seus versos, um real absoluto - contraposto à reslidede mundana, terrena, efêmera - , o qual é almejado pelo poe ta (como se depreende das ültimas estrofes), sendo o vento o intermediário que unifica os dois planos (o poeta pede que o vento leve seu lamento, na primeira estrofe). O vento simboliza, desse modo, a energia que daria ensejo a uma superação das limitaçōes da condição humana, encaminhando-a para a totalidade, o eterno, como parece ademais sugerir o mesmo Tasso da Silveira, na passagem transcrita.

O texto se desenvolve num tom de confidência, como se o poeta se dirigisse ao vento, tendo-o como interlocutor (observe-se o tratamento na $2 .^{a}$ pessoal, e desdobra, da primeira à vigesima sexta estrofes, as propriedades miticas $\left.{ }^{6}\right]$ deste mensageiro, o vento, para contrastá-las, nas quatro últimas, com o espaço (de limitações) onde está o poeta, que anseia por uma liberação.

Nessa perspectiva, o vento é sucessivamente caracterizado, verso a verso: ele erra dos campanários, solta pesadelos, conta velhas lendas, sabe mil segredos, e assim por diante (releia-se o poema). Importante notar a dimensāo espacial que se detecta nesse processo enumerativo dos poderes e faculdades do vento: "longe", "lá de tão longe", "no espaço/perdido", "lá da origem do mistério", "espaços ilimitados", "que andas além, perdido", "na esfera imensa", no qual se constata a presença do sema "distância". Acrescente-se a tal grupo a vasta quantidade de advérbios de lugar - "nas grandes torres tristonhas". "pelos bosques solitários", "pelas estradas sombrias", "nos campos e nas florestas", "nas harpas da tempestade", "nas ermas aldeias mortas", etc. - ancoradas num vocabulário de mistério, sobrenatural, noturno, tão do gosto dos simbolistas. $\left({ }^{7}\right) 0$ conjunto vãi delineando a auréola mítica que envolve o espaço ansiado, a que tem acesso o vento, o que é reforçado pelos vocábulos que vem grafados com maiúsculas: Imensidade, Infinito, Inferno.

Isso tudo articula, portanto, o real transcendente, objeto da busca do poeta. Desde os versos iniciais o poema situa o eu-li-

6 Entenderemos aqui mítics como sinbnimo de ab:oluto, transcendente, isto 6, um espoço, por assim dizer, ferá do humano.

7 Aproveitando passigem da Apresentaçāo de Tesso da Silveira, em que afirma que a dor de ser negro se transforma em dor do ser, paulatinamente, na poesia de Cruz e Sousa, seria interessante depreender esta metamorfose ao nivel vocabular a imagétco, tendo em visto que, em "Antifona", paema que inaugura sua produşäo, vislumbramos um vocabuiabrio com predominancia do branco, enquanta que no outro oxtroma, no qual poderíamos loca.izar "Velho vento", preponder a campo semsntico em torno do negro - sombrio, solurna. misterioss. Deixomos apenas sugerido o trabalho. 
rico num outro lugar, no qual parece não se encontrar (v. o substantivo "escárnio", dotando sem dúvida de uma conotação negativa a palavra "mundo"): "leva ao longe este lamento, / Além do escárnio do mundo".

O espaço do mundo / do poeta é retomado nas estrofles derradeiras, onde ingressam pronomes de $1 .^{\mathrm{a}}$ pessoa. Na vigésima sétima e vigésima oitava estrofes o poeta como que solicita a proteção e ajuda do vento: "dá-me o teu grande afago", "que a tua sombra me envolva", "que o teu vulto me console". Ainda no antepenúltimo quarteto, em seus dois versos finais, o poeta, ao nomear seu sentimento, grafa-o com maiúscula, propondo-o como afim do absoluto ("Infinito", "Imensidade", etc.), como que se gabaritando, por esse elogio e exaltação, a galpar até o transcendente (que seu sentimento se dissolva nos astros isto é, no real por onde transita o vento).

A penúltima estrofe explicita enfim a vontade de libertar-se do mundo onde está - das "ânsias" e "ansiedades" que configuram o situar-se em tal lugar - rumo ao espaço mítico "mais longínquas distâncias" (como vimos, este tem por peculiaridade a marca de ser longe) - para o que se atrela ao vento todo-poderoso: "Eu quero perder-me a fundo / no teu segredo nevoento".

Esquematizando, teríamos:
REAL
- ansiado pelo poeta
- espaço acessível ao vento
ABSOLUTO
- longe; transcendente, mítico
VENTO
(ascensão)
REALIDADE
- anseia libertar-se
(mundo)
- terreno, efêmero, mundano

Nossa leitura encontra respaldo em outros poemas de Cruz e Sousa. Basta recordar textos como "Cavador do Infinito", "Visionários", "Cárcere das almas", "Quando será?" ou o soneto "Almas das almas" (terceiro do tríptico intitulado "Pacto de almas"). Ela é ratificada ainda, neste ponto, pelo estudo crítico de Tasso da Silveira, que alude, a propósito do autor de Broquéis, à sua angústia metafísica, mostrando como que a dor de ser negro, presente nas primeiras composições, vai se metamorfoseando no decorrer da obra, canalizada e transfigurada numa "dor de ser", num "sobrevoar os abismos e as sombras da pobre terrenalidade", tornando-se "uma ansiedade total de 
Ora, o que foi visto casa com diversos dos tópicos arrolados por Hibbard, a propósito do ideário simbolista: o conteúdo está efetivamente "relacionado com o espiritual, o místico, o subconsciente"; há uma "concepção mística da vida"; um "interesse maior pelo particular e individual"; um "conhecimento intuitivo e não lógico"; uma "ênfase na imaginação e na fantasia"; um desprezo pela natureza, em proveito do místico e do sobrenatural; existe um interesse pelo espirito intimo (o sentimento do poeta) - tudo isso enfeixado no aspecto mais importante, que é a "evasāo da realidade e da sociedade contemporânea ". $\left({ }^{\prime \prime}\right)$

Quanto a isto, Tasso da Silveira nos lembra que a situação histórica que envolve a produção poética de Cruz e Sousa é a revolução de 93 . O dado, não obstante, não é explorado, evocando o crítico "o clima frio e as brumas hibernais ${ }^{n}\left({ }^{10}\right)$ do sul do país (o poeta nasceu em Santa Catarina) como também responsáveis pela eclosão do Simbolismo entre nós, numa reedição, a nosso parecer, de um determinismo tainiano.

Devemos ultrapassar a pura catalogação de traços de um estilo de época. Recorremos então a Alfrdo Bosi, mais feliz ao caracterizar de que se evadiria o poeta simbolista. Escreve ele: O Parnaso legou aos simbolistas a paixão do efeito estético. Mas os novos poetas buscavam algo mais: transcender os seus mestres para reconquistar 0 sentimento de totalidade que parecia perdido desde a crise do Romantismo. A arte pela arte de um Gautier e de um Flaubert é assumida por eles, mas retificada pela aspiraçāo de integrar a poesia na vida cósmica e conferir-lhes um estatuto de privilégio que tradicionalmente caberia à religião ou à filosofia. Visto à luz da cultura européia, o Simbolismo reage às correntes analíticas dos meados do século, assim

8 Cruz e Sousd, op. cit., Apresentaçäo, pp. 7 10.

9 Hibbard, loc. cit.. O autor fala ainda, com traços simbolistas, em "tom altamente poético" e em "linguagem ornada, colorida, exótica, poética". Ora, tais aspectos se ap icariam, talvez, à poesia em uma acepçāo bem ampla, nāo servindo para especificar, na maneira que os propōe Hibbard, a estética simbolista. Isso sem nos cetermos no impiessionismo crítico destas observaşōes, extremamente vagas. Hibbard parece ainda nāo distinguir as características estéticas (formais) das temáticas, nāo aprofundando, tampouco, a relação do Simbolismo com o seu tempo, indispenśbvel para que compreendêssemos a evasāo da realidade levada a cabo pelo poeta de então. Nos mesmos erros incorrem os professors brasileiros que adotam os termos de Hibbard - Afrânio Coutinho e Domício Proença Filho -, sendo que pela última lacuna apontada, na medida em que Hibbard é citado pelo autor de Introduçäo literatura no Brasil apenas com seus tópicos sobre a estética simbolista, cabe bem mais responsabilizar os críticos brasileiros.

10 Apresenteção, p. 5. 
como o Romantismo reagiria à llustração triunfante em 89. Ambos os movimentos exprimem o desgosto das soluções racionalistas e mecânicas e nestas reconhecem o correlato da burguesia industrial em ascensão; ambos recusam-se a limitar a arte ao objeto, a técnica de produzi-lo, a seu aspecto palpável; ambos, enfim, esperam ir além do empírico e tocar, com a sonda da poesia, um fundo comum que susteria os fenômenos, chame-se Natureza, Absoluto, Deus ou Nada. ${ }^{11}$ ]

Bosi prossegue, referindo-se ao fato de que as revoluções burguesas, na civilização ocidental, acarretaram a perda da vivência religiosa dos símbolos, uma vez que aqueles que as impulsionavam se apegaram ao cientificismo, predominante na época. A resistência a esse estado de coisas fica a cargo dos "estratos pré-burgueses ou anti-burgueses, isto é, dos aristocratas ou das baixas classes médias, postas à margem da industrialização". $\left({ }^{12}\right)$ Convém evocar a situação do poeta face à industrialização e à implantação do capitalismo no ocidente: desaparecendo a aristocracia, classe cujos mecenas asseguravam em larga escala o escoamento da produção artística em geral, o poeta se defronta com a necessidade de sobrevivência, com um mundo cujos valores (materiais) não endossa, perdendo o seu status e função social, gerando um clima de oposição cultural, desde o Romantismo. $\left({ }^{13}\right)$

Bosi verticaliza mais adiante o quadro:

A crise repropõe-se no último quartel do século XIX, quando a segunda revolução industrial, já de índole abertamente capitalista, traz à luz novos correlatos ideológicos: cientismo, determinismo, realismo "impessoal". Do âmago da inteligência européia surge uma oposição vigorosa ao triunfo da coisa e do fato sobre o sujeito - aquele sujeito a quem o otimismo do século prometera o paraíso mas não dera senão um purgatório de contrastes e frustraçōes. $\left({ }^{14}\right)$

Inferimos destas considerações que o simbolista, sentindo-se relegado por uma sociedade que se industrializa e adere em definitivo ao capitalismo, compensa esta marginalização perseguindo valores mais altos, metafísicos e espirituais, descar-

II Alfredo Rosi, História concisa da literatura brasiieira, 2.a ed. (São Paulo: Ed. Cultrix, 1976), p. 293.

12 Idem, p. 293.

13 A esse respeito ver, por exemplo, Affonso Romano de Sant'Anna, "O de-emprego do poeta", in Por um novo conceito de literatura brasileira (R:o de Janeiro: Liv. Eldorado, 1977).

14 Bosi, cit., p. 294. 
tando o matzrialismo circundante e dignificando a palavra poética, única capaz de habilitá-lo a dar o salto.

Este mal-estar na civilização industrial e capitalista, subjacente ao Simbolismo europeu, nāo pode ser vislumbrado, com - mesmo perfil, no cenário brasileiro, uma vez que, na segunda metade do século passado, nosso país estava longe de viver as conseqüências de uma industrialização (o que só viria a ocorrer nas primeiras décadas deste século), bem como nosso capitalismo ainda era deveras incipiente. Com esta anotação, percebemos que é possivel rastrear aqui o problema da dependência cultural: nosso Simbolismo, um Parnasianismo tardio (as duas tendências conviveram, inclusive), continua imitando modelos estrangeiros, sendo uma poesia desvinculada, em certa medida, de nossa realidade.

Escrevemos "em certa medida", pois Cruz e Sousa era negro e, como tal, na sociedade brasileira da época, que recém-alforriara os escravos mas continuava votando desprezo pelos homens de cor, estava sujeito a ser hostilizado pelo branco. Este desprezo é contrabalançado, no caso de "Velho vento", pelo enaltecer do sentimento do poeta, que o credencla para ascender ao absoluto, já que aquele é análogo aos componentes do real transcendente a que aspira. E a problemática do simbolista em geral, formulada na versäo de Cruz e Sousa: o poeta é negro, logo inferior, marginal, mas sua emoçāo, vertida em poesia, o eleva.

Reparamos com isso que, arrancando de um poema, confrontando o resultado de sua leitura com tópicos do Simbollsmo, recorrendo ao contexto que sustenta este estilo de época $e$, finalmente, reportando-nos a um dado biográfico, desembocamos num veio pelo qual poderíamos enveredar, desde que nos propuséssemos a um maior e mais complexo adentramento na produção literária do poeta catarinense: a questão do negro, figura excluida pela sociedade escravocrata brasileira do Segundo Império (e mesmo depois de proclamada a Abolição $\left({ }^{15}\right)$ ) e, à exceção de uns poucos, como Castro Alves, pela literatura do período, tematizada na obra do autor de Faróis, conjugada com a angústia metafísica, verdadeiro esforço por resolvê-la poeticamente.

15 V. Octavio lanni, As metamorfoses do escravo (55̃o Paulo: DIFEL, 1962 ). 


\section{RESUMO}

Este é um trabalho, antes de tudo, didático. Os estudantes de Literałura encontram dificuldade em analisar textos e, ao fazê-lo, geralmente recorrem aos estilos de época, modelo que se encontra mais acessível à consulta. O estudo aborda um poema de Cruz e Souso e recorre a traços da estética simbolista, mas procura ultrapassar tal tipo de indagação, acenando para um questionamento do contexto histórico e social, se esforçando por mostrar a viabilidade de uma análise que, embora passando pelo esfilo de época, a ele não se restrinja. A utilização de bibliografia ao alcance dos universitários de Letras, sem maiores extrapolações, é proposital. 